\title{
$\nabla$
}

\section{Off-label use of rituximab in dermatology: pemphigus treatment ${ }^{*}$}

\section{Uso off-label do rituximab na dermatologia: tratamento dos pênfigos}

\author{
Lislaine Bomm ${ }^{1}$ \\ João Luz Sodré \\ Alexandre Carlos Gripp ${ }^{4}$
}

\author{
Tainá Scalfoni Fracaroli² \\ Aline Bressan ${ }^{3}$
}

DOI: http://dx.doi.org/10.1590/abd1806-4841.20131905

\begin{abstract}
Since its approval in 1997 by the FDA (United States Food and Drug Administration), rituximab has been used for certain B-cell lymphomas and treatment-resistant rheumatoid arthritis. Nevertheless, over the past 14 years, many case reports have demonstrated the efficacy of off-label rituximab in several dermatological inflammatory conditions. This study describes two cases of pemphigus vulgaris and two cases of pemphigus foliaceous that were treated with rituximab at $375 \mathrm{mg} / \mathrm{m} 2$ once a week for 4 weeks, and that responded well to treatment. Keywords: biological treatment; immunosuppressive agents; pemphigus

Resumo: Desde a sua aprovação em 1997 pela FDA (United States Food and Drug Administration), o rituximab tem sido utilizado para o tratamento de alguns linfomas de células B e da artrite reumatoide resistente à terapia convencional. Porém, ao longo dos últimos 14 anos, muitos relatos demonstraram a eficácia do uso off-label do rituximab em várias afecções dermatológicas. Neste estudo, relatamos dois casos de pênfigo vulgar e dois casos de pênfigo foliáceo que foram tratados com rituximab, na dose de $375 \mathrm{mg} / \mathrm{m} 2$ uma vez por semana durante 4 semanas, e que apresentaram boa resposta ao tratamento.

Palavras-chave: Imunossupressores; Pênfigo; Tratamento biológico
\end{abstract}

Rituximab is a murine-human chimeric monoclonal antibody against CD20 that induces the depletion of B-cells in vivo. Rituximab acts at the CD20 receptor. CD20 is expressed specifically on the surface of B lymphocytes throughout differentiation, from the pre-B-cell to mature B-cell stage, but not on plasma cells or stem cells. ${ }^{1}$ This differential expression might explain why serum immunoglobulin levels do not decrease after treatment and why B-cells typically begin recirculating within 6 months of therapy.
Rituximab binds human complement, affecting complement-dependent cell lysis and antibody-dependent cellular cytotoxicity, and can disrupt signaling pathways and trigger apoptosis. ${ }^{2}$

Its FDA-approved indications are only for nonresponsive or relapsed rheumatoid arthritis and lowgrade follicular CD20+ lymphoma. However, off-label applications for autoimmune diseases, such as pemphigus, systemic lupus erythematosus, and angioedema, have emerged in recent years.

Received on 31.05.2012.

Approved by the Advisory Board and accepted for publication on 30.07.2012.

* Work conducted at the Pedro Ernesto University Hospital - State University of Rio de Janeiro (HUPE-UERJ) - Rio de Janeiro (RJ), Brasil.

Conflict of interest: None

Financial Support: None

MD. Medical resident of dermatology at the University Hospital Pedro Ernesto - State University of Rio de Janeiro (HUPE-UERJ) - Rio de Janeiro (RJ), Brazil. MD. Medical graduate student in dermatology at the Pedro Ernesto University Hospital - University of the State of Rio de Janeiro (HUPE-UERJ) - Rio de Janeiro (RJ), Brazil.

MD. Dermatologist - physician at the Biological and Immunosuppressants Clinic of the Pedro Ernesto University Hospital - University of the State of Rio de Janeiro (HUPE-UERJ) - Rio de Janeiro (RJ), Brazil.

4 MD. Dermatologist - Hospital assistant and preceptor of outpatient dermatology - immunosuppressive and biological agents Pedro Ernesto University Hospital - University of the State of Rio de Janeiro (HUPE-UERJ) - Rio de Janeiro (RJ), Brazil. 
There are two officially approved dosages of rituximab. In non-Hodgkin lymphoma, rituximab is given as an IV infusion of $375 \mathrm{mg} / \mathrm{m}^{2}$ once weekly for 4-8 consecutive weeks as a single agent or in combination with chemotherapy regimens. In rheumatoid arthritis, the dosage is $2 \mathrm{IV}$ infusions of $1000 \mathrm{mg}$ given 2 weeks apart (days 1 and 15), along with methotrexate. In pemphigus vulgaris, the off-label protocol in the literature is a $375-\mathrm{mg} / \mathrm{m}^{2}$ IV infusion once weekly for 2-4 consecutive weeks. Another option is 375 $\mathrm{mg} / \mathrm{m}^{2} \mathrm{IV}$ once weekly for 8 consecutive weeks with 1 cycle of $2 \mathrm{mg} / \mathrm{kg}$ IVIG during weeks 4 and 8 , followed by a monthly dose of rituximab and IVIG cycles for 4 consecutive months. ${ }^{3}$

Pemphigus is an autoimmune blistering disease that affects the skin and mucous membranes, caused by circulating autoantibodies directed against desmogleins, which encompass desmosomal proteins that mediate keratinocyte adhesion. The binding of autoantibodies results in the loss of cell-cell adhesion and blister formation. Systemic steroids, in combination with immunosuppressive agents, are the mainstay of therapy in pemphigus and have dramatically improved the prognosis, but the adverse effects and complications from long-term therapy still contribute substantially to its morbidity and mortality. Alternative treatments such as pulse therapy with high doses of intravenous steroids, cyclophosphamide, azathioprine, human intravenous immunoglobulin, plasmapheresis and mycophenolate mofetil, can be used to positive effect. ${ }^{4}$ However, some patients remain refractory to treatment, even when used in combination or rotation. In refractory and clinical rapidly progressive cases we believe the use of rituximab may be beneficial, leading to a longer remission of the disease and faster clinical improvement, respectively.
We present four cases of pemphigus treated with rituximab, taking into regard refractoriness to conventional treatments or clinical rapidly progressive cases. Table 1 shows the clinical data of these patients, including the age, sex, adjuvant, and assessment after infusion, with adverse effects, response, monitoring, and maintenance therapy. Patient number 1 had pemphigus vulgaris with a rapid and progressive evolution, with extensive mucosal involvement that did not respond to systemic corticosteroids taken in high doses (pulses of methylprednisolone $30 \mathrm{mg} / \mathrm{kg}$ and prednisone $1-2 \mathrm{mg} / \mathrm{kg}$ ) (Figure $1 \mathrm{~A}$ ). The use of rituximab brought about improvement within 15 days and the patient remained in remission for two and a half years, when he presented new mucosal lesions, but they were less intense and easily controlled with steroids (Figure 1B). The other patients remain without disease activity, with gradual reduction of maintenance medication (Azatioprine 1$2 \mathrm{mg} / \mathrm{kg}$, in gradual reduction) except patient number 2 who is in complete remission without medication. We observed that patients with pemphigus foliaceus had a slower response to therapy, which is also the case with other therapies, but we found no justification for this in the literature.

Serious adverse reactions to rituximab are very rare. They include: angina, adverse drug reactions, intestinal obstruction, lymphocytopenia, anemia, recurrent hepatitis $B$, progressive multifocal leukoencephalopathy, etc. The most common adverse effects are associated with infusion reactions, often related to the speed of administration and immune hypersensitivity reactions (fever, chills, bronchospasm, pruritus, hypotension and infection)., ${ }^{5,6}$ The cytokine-release syndrome can develop in patients receiving rituximab for lymphoma and is most common in patients with bulky adenopathy or bone marrow involvement.

TABLE 1: Comparison of laboratory tests of 15 patients with psoriasis followed up in an outpatient clinic, before and after the use of immunobiologicals

\begin{tabular}{|c|c|c|c|c|c|c|}
\hline $\begin{array}{l}\text { Patient/Sex/ } \\
\text { Age years }\end{array}$ & $\begin{array}{l}\text { Pemphigus } \\
\text { Type }\end{array}$ & Adjuvant Therapy & $\begin{array}{l}\text { Adverse } \\
\text { Effects } \\
\text { (weeks) }\end{array}$ & $\begin{array}{l}\text { Response after } \\
\text { Rituximab infusion }\end{array}$ & $\begin{array}{l}\text { Follow-up } \\
\text { (months) }\end{array}$ & $\begin{array}{l}\text { Maintenance } \\
\text { Therapy }\end{array}$ \\
\hline $\begin{array}{l}1 / \mathrm{M} / 50 \\
\text { (Figure 1A } \\
\text { and 1B) }\end{array}$ & $\mathrm{PV}^{*}$ & $\begin{array}{l}\text { Prednisone 80mg/ } \\
\text { day + Azathioprine } \\
150 \mathrm{mg} / \text { day }\end{array}$ & no effects & 2 & 24 & Azathioprine \\
\hline $2 / \mathrm{M} / 18$ & $\mathrm{PF}^{* *}$ & $\begin{array}{l}\text { Azathioprine } \\
150 \mathrm{mg} / \text { day }\end{array}$ & no effects & 20 & 11 & Azathioprine \\
\hline $3 / F / 31$ & PV & $\begin{array}{l}\text { Prednisone 60mg/ } \\
\text { day + Azathioprine } \\
150 \mathrm{mg} / \text { day }\end{array}$ & no effects & 12 & 8 & $\begin{array}{l}\text { Prednisone 20mg/ } \\
\text { day + Azathioprine }\end{array}$ \\
\hline $4 / \mathrm{M} / 35$ & $\mathrm{PF}$ & Prednisone 50mg/day & no effects & 24 & 11 & Azathioprine \\
\hline
\end{tabular}



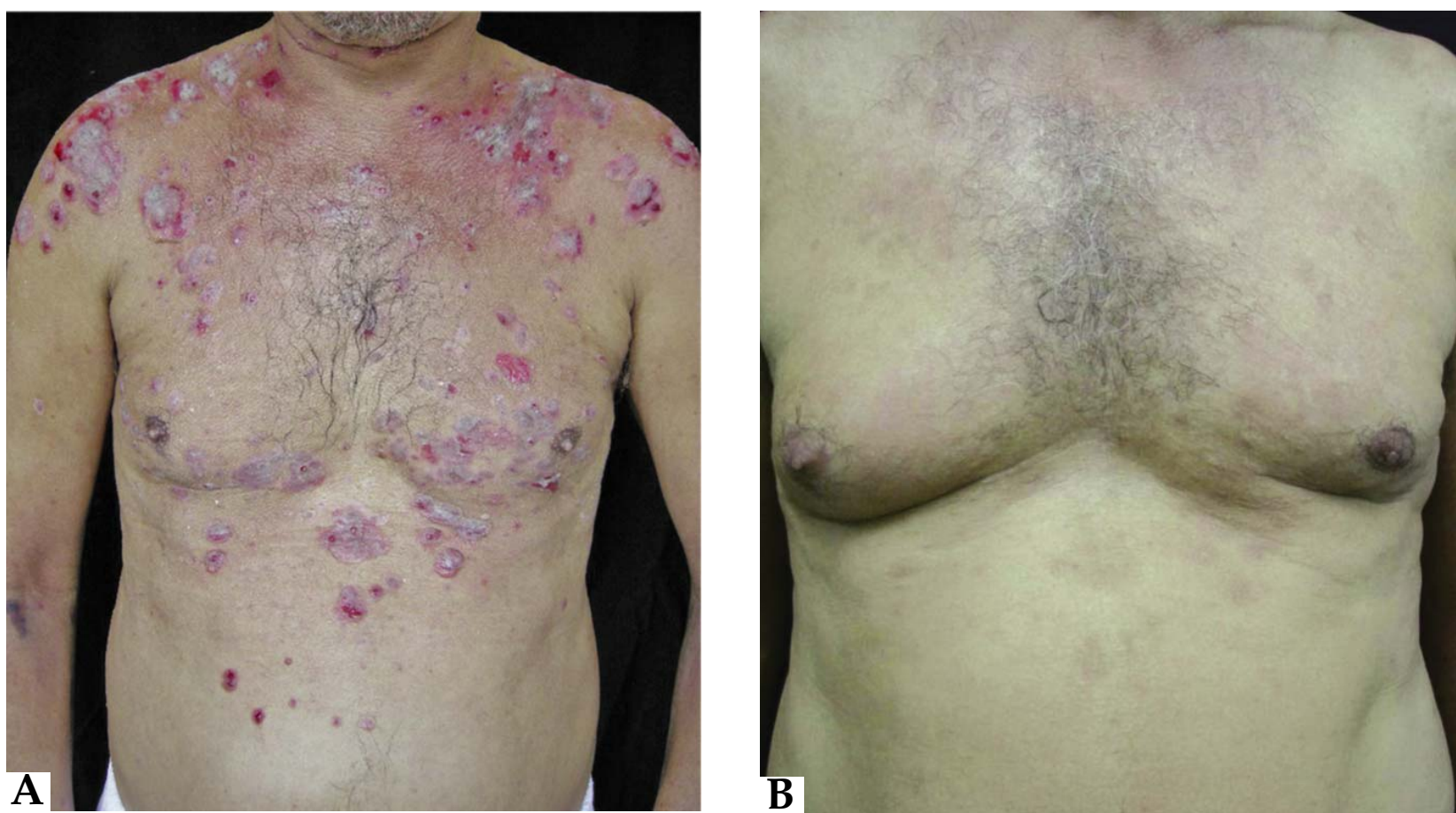

Figure 1: A. Patient with pemphigus vulgaris before the use of rituximab; B. Patient with pemphigus vulgaris after the use of rituximab

Although none of the patients in our study experienced these serious side effects, the long-term consequences of rituximab therapy in patients with autoimmune diseases are unknown. These findings underscore the need for further study of this drug to optimize its efficacy and safety in dermatology.

Therefore, rituximab is an emerging therapy for many autoimmune diseases such as pemphigus and connective tissue diseases. In these cases, off-label alternative treatment remains an option, especially for recalcitrant and rapidly progressive cases, or when conventional therapy is contraindicated. However, further prospective, controlled studies are needed to determine the effective dose, the role of adjuvant therapies, and to determine whether B cells depleted for an extended period may be the mechanism to achieve long-term clinical remission. It is also necessary to evaluate the cost-effectiveness of long-term treatment since 4 applications of $375 \mathrm{mg} / \mathrm{m}^{2}$ cost on average 16 thousand dollars.

\section{REFERENCES}

1. Carr DR, Heffernan MP. Off-label uses of rituximab in dermatology. Dermatol Ther. 2007;20:277-87.

2. Fatourechi MM, el-Azhary RA, Gibson L. Rituximab: applications in dermatology. Int J Dermatol. 2006;45:1143-55.

3. Emer JJ, Wolinsky C. Rituximab: a review of dermatological applications. J Clin Aesthet Dermatol. 2009;2:29-37.

4. Cianchini G, Corona R, Frezzolini A, Ruffelli M, Didona B, Puddu P. Treatment of severe pemphigus with rituximab. Arch Dermatol. 2007;143:1033-8.

5. Diab M, Galina K, Kurtz E. Treatment of refractory pemphigus erythematosus with rituximab. Int J Dermatol. 2008;47:1317-8.

6. Allen KJ, Wolverton SE. The efficacy and safety of rituximab in refractory pemphigus: a review of case reports. J Drugs Dermatol. 2007;6: 883-9.

7. Müller R, Hunzelmann N, Baur V, Siebenhaar G, Wenzel E, Eming R, et al. Targeted immunotherapy with rituximab leads to a transient alteration of the $\lg G$ autoantibody profile in pemphigus vulgaris. Dermatol Res Pract. 2010;2010:321950. doi: $10.1155 / 2010 / 321950$

\author{
MAILING ADDRESS: \\ Lislaine Bomm \\ Boulevard 28 de setembro, 66 \\ 20551-030 - Rio de Janeiro - RJ \\ Brazil \\ E-mail: lislainebomm@gmail.com
}

How to cite this article: Bomm L, Fracaroli TS, Sodre JL, Bressan A, Gripp AC. Off-label uses of rituximab in dermatology: pemphigus. An Bras Dermatol. 2013;88(4):676-8. 